\title{
TOMADA DE CONTAS ESPECIAL. UM IMPORTANTE MECANISMO DE CONTROLE NO ÂMBITO DOS TRIBUNAIS DE CONTAS
}

\author{
SPECIAL ACCOUNT AUDIT. AN IMPORTANT CONTROL INSTRUMENT WITHIN THE AUDITING
}

COURTS OF AUDIT

AUDIT DU COMPTE SPÉCIAL. UN MÉCANISME DE CONTRÔLE IMPORTANT DANS LES COURS DES COMPTES

\author{
Renata Constante Cestari* \\ César Augusto Martins Carnaúba** \\ Marcello de Oliveira Gulim ${ }^{* * * *}$ \\ Alexandre Manir Figueiredo Sarquis ${ }^{* * * *}$
}

Resumo:

Visa o presente trabalho a demonstrar as vantagens da utilização da Tomada de Contas Especial (TCE) como forma de apuração eficiente e célere de irregularidades cometidas por aplicadores de recursos públicos.

Palavras-chave: Direito Financeiro. Controle externo. Tribunal de Contas. Tomada de Contas Especial.

\begin{abstract}
:
This paper intends to set forth the advantages of using the Special Account Audit as an efficient and expeditious instrument of investigation of irregularities committed by public resources agents.
\end{abstract}

Keywords: Financial law. External audit. Court of Audit. Special Account Audit.

Résumé:

Cette étude vise à démontrer les avantages de l'utilisation de la Audit du Compte Spécial comme un moyen d'enquête efficace et rapide des irrégularités commises par des applicateurs de ressources publiques.

Mots-clés: Droit Financier. Contrôle externe. Cour des Comptes. Audit du Compte Spécial.

\footnotetext{
* Especialista em Processo Civil pela Universidade Federal de Goiás. Mestranda da Faculdade de Direito da Universidade de São Paulo. Procuradora do Ministério Público de Contas do Estado de São Paulo.

** Estudante de graduação na Faculdade de Direito da Universidade de São Paulo. Estagiário do Ministério Público de Contas do Estado de São Paulo.

*** Estudante de graduação na Faculdade de Direito da Universidade de São Paulo. Estagiário do Ministério Público de Contas do Estado de São Paulo.

***** Estudante de graduação na Faculdade de Direito da Universidade de São Paulo. Auditor do Tribunal de Contas do Estado de São Paulo.
} 
1. Introdução

O dever de prestar contas é uma preocupação inerente ao Estado Democrático de Direito, visto que a verba pública é utilizada por representantes eleitos pelo povo de modo democrático, sendo necessária que sua utilização esteja balizada pela legalidade e interesse público.

Para tanto, a Constituição Federal elucida que a vontade do administrador deve corresponder à vontade do povo, porquanto "todo o poder emana do povo, que exerce por meio de representantes eleitos ou diretamente, nos termos desta Constituição" (art. $1^{\circ}$, parágrafo único, CF). ${ }^{1}$ Portanto, a prestação de contas é um dos mecanismos que o Estado detém para controlar seus gestores, uma vez que a transparência e publicidade das contas públicas permitem aos administrados aferir se seus representantes estão destinando de forma correta as receitas a eles distribuídas.

A preocupação com a probidade dos gastos públicos encontra respaldo, também, na Declaração dos Direitos do Homem e do Cidadão (Revolução Francesa), ao dispor em seu art. 15 que "la Société a le droit de demander compte à tout Agent public de son administration".

Nesse sentido, a evolução do orçamento público, enquanto essencial instrumento mediante o qual o Estado atua sobre a economia (OLIVEIRA, 2013, p. 401), acompanhou a preocupação intrínseca do Estado Democrático de Direito em garantir a probidade da destinação de seus recursos, que ganhou força, principalmente, durante a Revolução Francesa com a promulgação da Declaração mencionada.

A evolução do orçamento público, destarte, decorreu da evolução da conjuntura política e social da sociedade, haja vista que as demandas de outrora se modificaram e já não correspondem às estruturas e necessidades atuais.

Com isso, na acepção do dever de prestar contas, diversas foram as experiências orçamentárias. O orçamento Tradicional, por exemplo, adveio da necessidade de estruturação, ao menos genérica, das receitas e despesas públicas, sem, contudo, se preocupar com um planejamento pormenorizado a fim de se desenvolver alguma política pública. Seria uma peça meramente contábil-financeira balizada majoritariamente no interesse estatal de atingir seus objetivos e metas.

Consoante o ensinamento de Celso Antônio Bandeira de Mello (apud OLIVEIRA, 2013, p. 643), "se o Estado de Direito supõe que todas as condutas estatais mantenham-se aprisionadas aos parâmetros prétraçados que lhe regulam os comportamentos, para que o princípio da legalidade se imponha como um todo íntegro, sem fissuras, é indispensável não apenas sua submissão ao controle judicial, quando sua conduta seja agressiva aos direitos subjetivos, mas é requisito também que exista um mecanismo controlador de toda a ação estatal, graças ao que possa ser reconduzido à legalidade, mesmo quando de sua conduta não haja resultado violação de direito individual". 
Evoluiu-se, dessa experiência, para Orçamento Desempenho, o qual correspondeu às angústias dos administrados em terem ciência do local em que a verba pública está sendo alocada e por qual motivo. A transparência começou a ser cobrada, assim como um bom desempenho por parte do gestor ao destinar a verba pública, de modo a não macular os recursos com interesses alheios ao público. A prestação de contas, peça de importantíssima relevância para garantia da boa destinação dos recursos, tornouse indispensável para demonstrar à população quais as direções dos recursos dadas pelo governo. Buscou-se, portanto, compreender os desdobramentos daquele gasto e os seus resultados.

O terceiro tipo de orçamento, utilizado pelo Brasil atual, diz respeito ao Orçamento Programa, no qual há uma preocupação de fato com planejamento das ações do governo à medida que o gestor teria metas e objetivos a serem cumpridas no decorrer do exercício financeiro (LEITE, 2016, p. 90).

Esse planejamento orçamentário ganha concretude com a edição periódica das conhecidas leis orçamentárias, quais sejam (i) Plano Plurianual, (ii) Lei de Diretrizes Orçamentárias e (iii) Lei Orçamentária Anual.

As três peças técnicas, são de relevante importância para a manutenção da probidade administrativa com os gastos executados pelos representantes do povo, uma vez que servem de baliza ao bom desenvolvimento das finanças públicas e, consequentemente, aos interesses inerentes à população. O gestor, assim sendo, deve observar os ditames orçamentários previstos nessas leis com intuito de atender ao interesse público e às demandas da sociedade, visto que as receitas e despesas destinam-se a cumprir metas e objetivos que beneficiem os administrados, sendo condenado qualquer tipo de desvio de finalidade ou prática que culmine em dano ao erário.

As prestações de contas (dentre elas a Tomada de Contas Especial - TCE), enquanto instrumentos legítimos para a persecução da boa gestão dos recursos públicos se afiguram como importante instituto, por meio do qual o Estado pode dar concretude ao ideal de realização correta e proba de suas despesas. As benesses destes instrumentos de controle influenciam na probidade e eficiência administrativa, haja vista a possibilidade de se apurar a conduta em si do gestor, que deixou de prestar contas ou que aplicou indevidamente a verba pública.

Destarte, é mister fazer algumas considerações sobre a possibilidade de uso de uma das espécies de instrumento de controle, qual seja, a Tomada de Contas Especial, com vistas a aprimorar a fiscalização das contas por parte dos Tribunais de Contas. Para tanto, pretende-se realizar uma análise mais detida a respeito do instituto - seus fundamentos legais, os ritos a serem observados -, bem como procurar precedentes em outras unidades da Federação. 


\section{Conceito e natureza jurídica da TCE}

Conforme conceito disponibilizado no sítio eletrônico da ControladoriaGeral da União, Tomada de Contas Especial é um "Instrumento de que dispõe a Administração Pública para ressarcir-se de eventuais prejuízos que lhe forem causados, sendo o processo revestido de rito próprio e somente instaurado depois de esgotadas as medidas administrativas para reparação do dano". ${ }^{2}$ Trata-se, depreende-se desde logo, de medida excepcional, de natureza administrativa, em razão de somente poder ser instaurada após comprovação de esgotamento, pela via administrativa interna, de esforços para recompor o erário público.

Jorge Ulisses Jacoby Fernandes (2014) relata em sua obra “Tomada de contas especial: processo e procedimento nos tribunais de contas e na administração pública" que esse processo de natureza excepcional tem como objetivo apurar a responsabilidade por omissão ou irregularidade no dever de prestar contas ou por dano causado ao erário. Seria "o processo devidamente formalizado, com rito próprio, para apurar responsabilidade por ocorrência de dano à Administração Pública e obtenção do respectivo ressarcimento" (LIMA, 2011, p. 271), tendo como objetivo apuração dos fatos, a fim de dar materialidade aos indícios; identificação dos responsáveis, delimitando a autoria; quantificação do dano para mensurar o valor que deve ser devolvido; por fim, obtenção do ressarcimento.

Note-se que a TCE não se confunde com procedimento administrativo disciplinar, pois sua real intenção é a de zelar pela preservação do erário, ou, como já decidido pelo STF, da coisa pública:

A tomada de contas especial não consubstancia
procedimento administrativo disciplinar. Tem por escopo a
defesa da coisa pública, buscando o ressarcimento do dano
causado ao erário. Precedente (MS 24.961, Rel. Min. Carlos
Velloso, DJ de 4/3/2005). (MS 25.880, Rel. Min. Eros Grau,
julgamento em 7/2/2007, Plenário, DJ de 16/3/2007).

Pode-se dizer que a TCE tem natureza jurídica de "julgamento", ou seja, decide com a definitividade peculiar ao controle externo. Com razão, observa-se um núcleo duplo do art. 71, inciso II, que, de fato, abarca duas competências. A primeira refere-se às "contas" no sentido do julgamento anual, regular, do exercício - as Tomadas de Contas Ordinárias. A segunda refere-se às "contas" no sentido de julgar um fato específico irregular que resultou prejuízo ao erário, confira:

Disponível em: $<$ http://www.portaldatransparencia.gov.br/glossario/DetalheGlossario.asp?letra=t>. Acesso em: 4 abr. 2016. 
Art. 71. O controle externo, a cargo do Congresso Nacional, será exercido com o auxílio do Tribunal de Contas da União, ao qual compete:

II - julgar as contas dos administradores e demais responsáveis por dinheiros, bens e valores públicos da administração direta e indireta, incluídas as fundações e sociedades instituídas e mantidas pelo Poder Público federal, $e$ as contas daqueles que derem causa a perda, extravio ou outra irregularidade de que resulte prejuízo ao erário público; (grifo nosso).

Dessa forma, afirmamos que o julgamento das contas e o julgamento da TCE não se prejudicam, mas ao contrário, somam-se. A existência de prejuízo ao erário e o intuito de seu ressarcimento são condições essenciais para que a TCE possa ser formada. Não se forma para apreciar simples violação de princípio, nem de fato para o qual não seja possível o ressarcimento.

3. Elementos da Tomada de Contas Especial.

Em primeiro, ressalta-se que a TCE possui rito próprio, e isso porque não se confunde com a prestação de contas ordinária ou com qualquer outro diálogo institucional entre Tribunal de Contas e ente fiscalizado. Ela é instaurada em separado - diferentemente do que acontece com recursos geridos pela autoridade submetida a julgamento, por exemplo.

Com efeito, o art. $8^{\circ}$ da Lei Orgânica do TCU (Lei n. 8.443, de 16 de julho de 1992) prevê a instauração da Tomada de Contas Especial diante de um rol de hipóteses de que resulte dano ao erário, como exemplo, a omissão no dever de prestar contas. Logicamente, instaura-se procedimento à parte para apuração dessas irregularidades.

Em face disso, conclui-se que a hipótese de instauração da TCE - respeitando o art. $8^{\circ}$ da LOTCU - depende da suposição de uma ilegalidade, e aí reside seu caráter excepcional, segundo o qual o possível ato em desconformidade com a legislação de regência mereça ser analisado no bojo de procedimento mais adequado para tanto.

Os Tribunais de Contas detêm autonomia para dispor e criar seus próprios mecanismos de controle, com seus respectivos ritos, desde que não contrariem as normas rígidas da Constituição Federal, como é o caso do processo de elaboração de parecer nas contas do Presidente, Governadores e Prefeitos.

Quando da inclusão de uma TCE em seu ordenamento jurídico, pode ocorrer dela não ter sido instruída obrigatoriamente pela Administração Pública, ou ainda, ser alargada a possibilidade de provocação da mesma, como, v.g., cidadãos, qualquer autoridade pública, órgãos internos dos Tribunais etc. 
Portanto, apesar de os Tribunais de Contas não serem obrigados a criar a TCE, devem os mesmos desenvolver outros instrumentos capazes de apurar a responsabilidade do gestor faltoso, na medida em que a competência especial atribuída a eles pela Carta Magna demonstra que o constituinte possuía clara preocupação com a conduta inadequada de gestores públicos, como será demonstrado a posteriori.

O processo e procedimento de TCE devem, a rigor, consubstanciarem com o direito material em voga (probidade dos gastos públicos), funcionando como um verdadeiro instrumento para obtenção da probidade administrativa como resultado. Acerca dessa instrumentalidade, lição de Bedaque (2011, p. 28-29):

Quanto mais consciência tiver o estudioso de processo das necessidades verificadas em sede de direito material, mais possibilidade terá de adequar os modelos ao objeto. Deve haver compatibilização entre a técnica processual e o escopo do processo. O processualista moderno está comprometido com resultados. Não mais se aceitam a indiferença e a neutralidade quanto aos objetivos.

O importante, deste modo, seria atingir a finalidade maior da competência especial atribuída ao Tribunal de Contas, que pode ser alcançada pela TCE ou por outro instrumento apto para tal. Contudo, o presente artigo tentará elucidar as benesses que esse instituto em específico poderá trazer para as Cortes de Contas, demonstrando ser ela uma solução pertinente para o cumprimento de seu objeto.

\section{Objeto da Tomada de Contas Especial}

Vistos, portanto, os elementos procedimentais que informam a TCE, devese atentar para seu objeto, qual seja, apurar o responsável por eventual dano ao erário, bem como obter o ressarcimento do prejuizo.

Na concisa definição de Reis (2009), dano ao erário é “o prejuízo da Fazenda Pública”. Entretanto, é essencial delimitar, ainda que sem pretensões de exaustividade, o que se pode considerar um efetivo dano ao erário, que enseje o ressarcimento se comprovada sua ocorrência. O próprio Tribunal de Contas da União, no enunciado n. 142 de sua Súmula jurisprudencial, já excepcionou a qualificação como dano ao erário, excluindo as meras irregularidades formais, uma vez que não seria vantajosa a instauração do procedimento em decorrência de montantes ínfimos. Leia-se:

Cabe a baixa na responsabilidade e o arquivamento do processo quando, nas contas de ordenador de despesa, dirigente ou administrador de entidade ou qualquer outra pessoa sob a jurisdição do Tribunal de Contas da União, for apurada infringência de disposição legal ou regulamentar aplicável ou verificada irregularidade de caráter formal, 
que não permita o julgamento pela regularidade e quitação, ou, tampouco - por não ser suficientemente grave ou individualizada - a conclusão pela irregularidade e cominação da multa prevista em lei, conforme Enunciados ns. 10, 11, 51 e 91 da Súmula da sua Jurisprudência.

Todavia, em matéria de Tomada de Contas Especial, constata-se a presença de ato normativo especial a esse respeito. Assim dispõe a Instrução Normativa n. 71/2012, do TCU: ${ }^{3}$

Art. $6^{\circ}$ Salvo determinação em contrário do Tribunal de Contas da União, fica dispensada a instauração da tomada de contas especial, nas seguintes hipóteses:

I - valor do débito atualizado monetariamente for inferior a $\mathrm{R} \$ 75.000,00$;

(...)

\section{Sujeitos das Tomadas de Contas Especial}

Conforme o art. $4^{\circ}$ da IN n. 71/2012, do TCU, respeitado o já demonstrado caráter excepcional do procedimento, deve a autoridade competente "providenciar a imediata instauração de tomada de contas especial, mediante a autuação de processo específico". Feito isso, encaminhar-se-á a TCE ao Tribunal de Contas, que julgará as condutas sob apreço. Dessa sequência de atos processuais se infere uma dualidade de sujeitos ativos: de um lado, a autoridade competente na qual se encontra lotado o responsável pelo dano ao erário; de outro, o próprio Tribunal de Contas, como decorrência de sua competência constitucional de julgar os administradores (art. 71, II), ou seja:
II - julgar as contas dos administradores e demais responsáveis por dinheiros, bens e valores públicos da administração direta e indireta, incluídas as fundações e sociedades instituídas e mantidas pelo Poder Público federal, e as contas daqueles que derem causa a perda, extravio ou outra irregularidade de que resulte prejuízo ao erário público;

Já no que se refere ao sujeito passivo, este encontra-se delimitado no art. 70, II ut mencionado. Convém mencionar que a questão também já foi enfrentada no

\footnotetext{
3 Atentamos aqui ao princípio da especialidade, segundo o qual "lex specialis derogat legi generali". A IN n. 71/2012, enquanto mais específica do que os fundamentos legais apontados anteriormente, evita o bis in idem, pois determina que haverá a prevalência da norma especial sobre a geral, sendo certo que a comparação entre as normas será estabelecida in abstracto.
} 
Incidente de Uniformização de Jurisprudência, requerido por representante do Ministério Público junto ao TCU, nos autos do TC-006.310/2006-0:

(...) Assim, claro resta que a simples ocorrência de prejuízo ao erário não constitui condição suficiente para que se submeta o caso à jurisdição especial de contas do TCU. É necessário, ainda, para tanto, que o prejuízo tenha decorrido de um ilícito causado pela conduta irregular de um gestor público, entendendo-se este conceito em sua acepção mais ampla, a qual compreende o agente público gestor, integrante dos quadros do Estado, e também qualquer pessoa a quem o Estado tenha, ainda que em caráter eventual, atribuído um múnus público. (...)

(...) Trata-se de uma competência constitucional do TCU que se pode traduzir como uma jurisdição especial de contas. Dos dispositivos constitucionais supracitados, depreende-se que essa jurisdição especial de contas, a qual, é sabido, tem sido levada a efeito em sede do procedimento da tomada de contas especial, deve ter lugar nas hipóteses em que presentes dois requisitos básicos. O primeiro é a ocorrência de um ilícito que tenha acarretado prejuizo direto ou indireto ao erário. $O$ segundo requisito é a constatação de que esse ilícito decorreu de uma conduta irregular de pessoa - física ou jurídica, pública ou privadaa quem se tenha confiado a gestão pública, assim entendida esta como a gestão de recursos de natureza estritamente pública, a gestão de recursos pelos quais a União responda ou, ainda, a gestão exercida por aquele que, em nome da União, tenha assumido obrigações de natureza pecuniária. (...) (TC 006.310/2006-0; Plenário; Natureza: Incidente de Uniformização de Jurisprudência; Entidade: Instituto Nacional de Colonização e Reforma Agrária - INCRA; Interessado: Ministério Público junto ao TCU). (g. n.)

Merece destaque o entendimento da Corte de Contas nacional, uma vez que exclui dos possíveis responsáveis os eventuais particulares que não guardem qualquer vínculo jurídico com o Estado. É uma posição diversa, por exemplo, da lei de improbidade administrativa (Lei n. 8.429, de 2 de junho de 1992), que abrange aquele que, "mesmo não sendo agente público, induza ou concorra para a prática do ato de improbidade ou dele se beneficie sob qualquer forma direta ou indireta".

Eis outro aspecto da TCE que celebra o devido processo, pois enquanto na Prestação de Contas Ordinária há pluralidade subjetiva no polo passivo e pluralidade de apontamentos, que os implicados se veem compelidos a contraditar em um libelo genérico, a Tomada de Contas Especial individualiza fatos e responsáveis. Reclama, pois, a notificação pessoal do Ordenador de Despesas ou implicado, aproximando-se do rito entabulado no Judiciário. 


\section{Fundamentos legais da TCE \\ 6.1. Fundamentos constitucionais}

A Constituição Federal de 1988 abre espaço à criação de instrumentos capazes de apurar as ações de gestores faltosos, sendo que, dentre eles, nada obsta a inclusão da TCE. Tudo isso nos termos do art. 71, inciso II, da Carta Magna, que atribui competência ao Tribunal de Contas para julgar as contas "daqueles que derem causa a perda, extravio ou outra irregularidade de que resulte prejuízo ao erário público".

A Constituinte, objetivando garantir a liberdade e limitar o poder (LENZA, 2013, p. 98), ${ }^{4}$ busca assegurar que os administradores - representantes da população destinassem receitas públicas em conformidade com o interesse público; para isso, faz-se necessária a utilização da prestação de contas.

Extrai-se dessa lógica garantista, de que é corolário o Estado Democrático de Direito, a necessidade de um processo e procedimento para apuração das contas daqueles que ocasionarem prejuízo ao erário, a ser realizado pelo Tribunal de Contas, quando de sua "competência especial” (SILVA, 2010).

Sua não instauração implicaria a premiação da conduta ilegal do administrador ímprobo e o estímulo em manter tal prática, afrontando diametralmente os princípios administrativos do art. 37 , caput, da CF.

\subsection{Fundamentos infraconstitucionais e infralegais}

A regulamentação da TCE em nível infraconstitucional é feita de forma complexa, em mais de um ato normativo. O primeiro que se destaca são as Leis Orgânicas dos Tribunais de Contas. A LOTCU, por exemplo, prevê o instituto em seus arts. $8^{\circ}$ e $9^{\circ}$ (com algumas outras remissões no texto da lei), que aqui pedimos vênia para transcrever:

Art. $8^{\circ}$ Diante da omissão no dever de prestar contas, da não comprovação da aplicação dos recursos repassados pela União, na forma prevista no inciso VII do art. $5^{\circ}$ desta Lei, da ocorrência de desfalque ou desvio de dinheiros, bens ou valores públicos, ou, ainda, da prática de qualquer ato ilegal, ilegítimo ou antieconômico de que resulte dano ao Erário, a autoridade administrativa competente, sob pena de responsabilidade solidária, deverá imediatamente adotar providências com vistas à instauração da tomada de

\footnotetext{
4 Segundo Manoel Gonçalves Ferreira Filho (1997, p. 14), "modernamente, é frequente designar a Constituição de tipo clássico de Constituição-garantia, pois esta visa a garantir a liberdade, limitando o poder. Tal referência se desenvolveu pela necessidade de contrapô-la à Constituição-balanço. Esta, conforme a doutrina soviética que se inspira em Lassalle, é a Constituição que descreve e registra a organização política estabelecida".
} 
contas especial para apuração dos fatos, identificação dos responsáveis e quantificação do dano.

$\S 1^{\circ}$ Não atendido o disposto no caput deste artigo, o Tribunal determinará a instauração da tomada de contas especial, fixando prazo para cumprimento dessa decisão.

$\S 2^{\circ}$ A tomada de contas especial prevista no caput deste artigo e em seu $\S 1^{\circ}$ será, desde logo, encaminhada ao Tribunal de Contas da União para julgamento, se o dano causado ao Erário for de valor igual ou superior à quantia para esse efeito fixada pelo Tribunal em cada ano civil, na forma estabelecida no seu Regimento Interno.

$\S 3^{\circ} \mathrm{Se}$ o dano for de valor inferior à quantia referida no parágrafo anterior, a tomada de contas especial será anexada ao processo da respectiva tomada ou prestação de contas anual do administrador ou ordenador de despesa, para julgamento em conjunto.

Além da Lei Orgânica, é possível encontrar algumas normas pertinentes à TCE no bojo dos Regimentos Internos. Novamente utilizando a Corte de Contas da União como parâmetro, pode-se observar o regramento do instituto em seus arts. 197 a 200 que, entretanto, ainda não adentram com a devida especificidade no rito do procedimento.

Esse nível de especificidade desejável é encontrado em atos normativos secundários, por via de regra, em instruções normativas. O TCU exauriu o assunto ao editar a IN n. 71/2012, que dispõe sobre o procedimento de instauração e julgamento da TCE.

Todavia, ao cotejar a necessidade de legislação inferior regulamentando a TCE e os ordenamentos jurídicos dos diversos entes da federação, constata-se que nem todas as Cortes de Contas nacionais o fizeram; como é o caso dos estados de São Paulo e Bahia, os quais detêm outras formas de controle.

Descendo mais um degrau na pirâmide kelseniana da hierarquia das normas, destaca-se que os Regimentos Internos dos Tribunais de Contas representam importante fonte para a cognição de seus procedimentos. Nesse sentido, além de São Paulo e Bahia - que não possuem a TCE -, o estado da Paraíba, na esteira destes, deixa de regular a Tomada de Contas Especial no Regimento Interno de seu Tribunal de Contas. É mister salientar que apenas a previsão na Lei Orgânica não é condição bastante para a instauração da TCE, uma vez que a ausência de normas sobre o rito a ser adotado geraria uma temerosa insegurança jurídica. 
Para conceder maior clareza a esse ponto, demonstremos esse mesmo dado através da tabela abaixo:

\begin{tabular}{|l|l|}
\hline \multicolumn{2}{|c|}{ Previsão legal da TCE } \\
\hline $\begin{array}{l}\text { Constituições Estaduais (e Lei Orgânica do } \\
\text { DF) }\end{array}$ & $\begin{array}{l}\text { Todos os estados brasileiros podem se utilizar } \\
\text { da Tomada de Contas Especial. }\end{array}$ \\
\hline Lei Orgânica do Tribunal de Contas do Estado & $\begin{array}{l}\text { Os Tribunais de Contas de São Paulo e Bahia } \\
\text { não preveem a TCE. }\end{array}$ \\
\hline $\begin{array}{l}\text { Regimento Interno do Tribunal de Contas do } \\
\text { Estado }\end{array}$ & $\begin{array}{l}\text { Os RI dos Tribunais de Contas de São Paulo, } \\
\text { Bahia e Paraíba não regulam o instituto. }\end{array}$ \\
\hline
\end{tabular}

\section{Vantagens na utilização da TCE}

O interesse público, quando desvirtuado, deve ser coibido de imediato, pois o ônus dromológico (quantidade de tempo em que se pratica a conduta inadequada) decorrente desse desvio de finalidade recai majoritariamente sobre a sociedade.

A crise de moralidade e eficiência inerente à conduta inadequada que gera prejuízo à administração deve ser resolvida de forma rápida a fim de se evitar que a prática se perpetue com o tempo, tendo em vista que a praxe pode transformar um ato irregular em conduta corriqueira e comum.

Valendo-se da lógica da administração gerencial, na qual se objetiva a busca por resultados de modo eficiente e com menor dispêndio de forças, a TCE traz benefícios que contemplam aspectos econômicos, processuais e morais, uma vez que restituirá o erário e moralizará sua administração com a coibição da conduta ímproba praticada pelo gestor por meio de sanção.

\subsection{Economia processual}

Um dos grandes benefícios que aperfeiçoará o desempenho das funções institucionais do Tribunal de Contas, de seus órgãos auxiliares e do próprio Ministério Público de Contas, diz respeito à economia processual.

A priori, cabe lembrar que a deliberação sobre as prestações de contas é apenas uma das competências das Cortes, dentre tantas outras. A análise das formalidades

5 O Tribunal de Contas do Estado da Bahia possui julgado (TCE/001554/2013, rel. Cons. João Bonfim, j. 4/2/2015) determinando a instauração da TCE na Secretaria de Desenvolvimento Urbano (SEDUR). Entretanto, a mesma decisão determinou a juntada dos autos à prestação de contas da SEDUR do exercício de 2009. Fato este que acaba por desnaturar o conceito proposto para a Tomada de Contas Especial, porque não se observou o rito próprio. Ademais, ante a falta de legislação de regência, a instauração da TCE por certo fere a segurança jurídica dos fiscalizados, que não possuem um mínimo necessário de calculabilidade e cognoscibilidade (ÁVILA, 2014) a respeito do procedimento a ser adotado. 
e execução inerentes às contratações dos entes públicos, convênios ou repasses de qualquer ordem também podem ser objeto da TCE.

Em relação aos contratos e utilizando como base de análise um sistema que julga a maioria dos contratos realizados por determinado ente, seja da administração direta, indireta ou de entidade que receba verbas públicas, tem-se que o dispêndio de forças do Tribunal, nesse sentido, se mostra exacerbado e, muitas vezes, desnecessário, haja vista seu objeto de análise amostral $^{6}$ acabar fiscalizando, muitas vezes, atos claramente regulares.

Mobiliza-se todo um aparato administrativo para realizar a análise de determinado contrato; confecciona-se relatório pormenorizado sobre as fases contratuais; remetem-se os autos para o Tribunal que, apesar de saber da clara regularidade da matéria, diante das análises anteriores, se vê obrigado a dar oportunidade de manifestação à Assessoria Técnica da Casa, à Procuradoria da Fazenda Nacional ou Estadual (se for o caso), ao Ministério Público de Contas e finalmente ao Ministro ou Conselheiro Relator do processo.

A mencionada persecução administrativa ocorre tanto para contratos regulares como para os manifestamente irregulares, porquanto todos, desde que respeitem o valor de alçada, devem passar pelo crivo do Tribunal de Contas.

A Tomada de Contas Especial funciona como um alento à eficiência administrativa, visto que apenas passariam à instrução, os contratos administrativos que tivessem apontamentos realizados pela fiscalização, provocados por denúncia ou por qualquer outro órgão da Corte, bem como pelo Ministério Público de Contas, e que, a princípio, gerassem algum prejuízo ao erário oriundo da conduta inadequada do gestor público.

O presente instituto desafogaria o Tribunal desses casos já tidos como regulares pela fiscalização, à medida que não seriam objeto de sua apreciação por não atenderem ao requisito essencial de análise: indício de irregularidade. Coaduna-se a essa lógica a noção de administração gerencial, ${ }^{7}$ pautada na eficiência, com claro interesse

Em procedimentos fiscalizatórios do Tribunal de Contas, em geral, é utilizado um método de análise por amostragem: o juízo competente analisa uma determinada quantidade de contratos regulares, regulares com ressalvas e irregulares. A amostragem se mostra como o melhor meio para obter informações, seja nos casos em que o exame de todos os itens auditáveis é inviável, seja porque o objeto auditável é constituído de vários itens, seja porque se distribui de forma pulverizada. Além disso, a amostragem resulta em aumento da confiabilidade: o exame de um número menor de itens pressupõe maior qualidade na análise.

7 Bresser Pereira (1996, p. 11-12), em percuciente análise sobre o tema, delineou os contornos da nova administração pública almejada pelo Estado brasileiro: (1) descentralização do ponto de vista político, transferindo recursos e atribuições para os níveis políticos regionais e locais; (2) descentralização administrativa, através da delegação de autoridade para os administradores públicos transformados em gerentes crescentemente autônomos; (3) organizações com poucos níveis hierárquicos ao invés de piramidal; (4) pressuposto da confiança limitada e não da desconfiança total; (5) controle por resultados, a posteriori, 
em otimizar resultados, noção essa implantada em âmbito nacional pela Emenda Constitucional n. 19/98.

Necessário esclarecer que, o contrato tido como sem vícios pela fiscalização e não analisado pelo Tribunal, não recebe o título de regular. Ele apenas não será julgado, podendo o ser, a qualquer momento em que alguém do povo, órgãos internos, autoridades públicas, Ministério Publico de Contas ou Conselheiro, levantar alguma suspeita sobre a idoneidade da contratação.

Assim sendo, a Tomada de Contas Especial implica a redução do número de processos no Tribunal, uma vez que não subiriam à Corte aqueles manifestamente regulares, redundando, destarte, na economia processual. A eficiência administrativa seria atendida, pois seu núcleo, que "é a procura de produtividade e economicidade e, o que é mais importante, a exigência de reduzir os desperdícios de dinheiro público, o que impõe a execução de serviços públicos com presteza, perfeição e rendimento funcional" (CARVALHO FILHO, 2013, p. 30), encontra-se como objetivo da TCE.

\subsection{Inelegibilidade em decorrência de ato de improbidade administrativa}

Outro efeito importante está na possibilidade de se punir o agente ímprobo com a consequente inelegibilidade, desde que configurada a irregularidade da aplicação dos recursos e o prejuízo ao erário e tenha agido com dolo.

A Lei Complementar n. 64/90 previu algumas hipóteses de inelegibilidade decorrentes da ocorrência de ato de improbidade que pode ser verificado por meio da Tomada de Contas Especial:

Art. $1^{\circ}$ São inelegíveis:

I - para qualquer cargo:

(...) g) os que tiverem suas contas relativas ao exercício de cargos ou funções públicas rejeitadas por irregularidade insanável que configure ato doloso de improbidade administrativa, e por decisão irrecorrível do órgão competente, salvo se esta houver sido suspensa ou anulada pelo Poder Judiciário, para as eleições que se realizarem nos 8 (oito) anos seguintes, contados a partir da data da decisão, aplicando-se o disposto no inciso II do art. 71 da Constituição Federal, a todos os ordenadores de despesa, sem exclusão de mandatários que houverem agido nessa

ao invés do controle rígido, passo a passo, dos processos administrativos; e (6) administração voltada para o atendimento do cidadão, ao invés de auto-referida. (grifo nosso). 
condição; (Redação dada pela Lei Complementar n. 135, de 2010)

(...) 1) os que forem condenados à suspensão dos direitos políticos, em decisão transitada em julgado ou proferida por órgão judicial colegiado, por ato doloso de improbidade administrativa que importe lesão ao patrimônio público $e$ enriquecimento ilícito, desde a condenação ou o trânsito em julgado até o transcurso do prazo de 8 (oito) anos após o cumprimento da pena; (Incluído pela Lei Complementar n. 135, de 2010) (g. n.).

Ao mencionar o art. 71, inciso II, da CF, o legislador quis possibilitar à administração pública a utilização da Tomada de Contas Especial para este fim, uma vez que a Lei Complementar n. 135/2010 (Lei da Ficha Limpa) - lei que incluiu os crimes de improbidade como causa de inelegibilidade - teve como objetivo principal proteger a probidade administrativa e a moralidade, conforme seu preâmbulo:

Altera a Lei Complementar n. 64, de 18 de maio de 1990, que estabelece, de acordo com o $\S 9^{\circ}$ do art. 14 da Constituição Federal, casos de inelegibilidade, prazos de cessação e determina outras providências, para incluir hipóteses de inelegibilidade que visam a proteger a probidade administrativa e a moralidade no exercício do mandato. (g. n.).

Também com esse sentido, a Lei de Improbidade Administrativa prevê que a omissão no dever de prestar contas redunda em crime que afronta os princípios da administração pública, in verbis:

Art. 11. Constitui ato de improbidade administrativa que atenta contra os princípios da administração pública qualquer ação ou omissão que viole os deveres de honestidade, imparcialidade, legalidade, e lealdade às instituições, e notadamente:

(...) VI - deixar de prestar contas quando esteja obrigado a fazê-lo;

Enquadra-se no caput a omissão de prestar contas, uma das hipóteses de incidência que dão causa à Tomada de Contas Especial.

É sabido que o dever de prestar contas adveio do art. 70, parágrafo único, da Constituição, e dessarte sua ausência implica a afronta aos princípios da administração entabulados no art. 37. Nesse ínterim, discorrendo sobre o art. 11, inciso VI, da Lei de Improbidade, Calil Simão (2011, p. 179) explica sobre as entidades recebedoras de recursos: 
Os beneficiários de transferências de recursos, incluindo auxílios, subvenções, contribuições ou outra forma de transferência de valores por intermédio de órgãos e entidades da administração direta, indireta, de fundações instituídas e mantidas pelo Poder Público e de suas entidades para-estatais, prestarão contas ao órgão ou entidade repassador quanto à boa e regular aplicação de tais recursos, apresentando documentos e informações necessários à composição das tomadas e prestações de contas dessas unidades jurisdicionadas, e não ao Tribunal de Contas (Lei n. 8.443/92, art. $3^{\circ}$ ). Não sendo prestadas contas pela entidade recebedora à entidade repassadora, será instaurada tomada de contas especial com relação à entidade recebedora. (g. n.)

Caso o gestor público incorra em ato de improbidade administrativa por omissão no dever de prestar contas, desde que comprovado o dolo, cairá sobre ele as sanções previstas no art. 12 da Lei de Improbidade, além da possível inelegibilidade consoante art. $1^{\circ}$, inciso I, alínea "g”, da Lei Complementar n. 64/90, consoante jurisprudência do TSE:

ELEIÇÕES 2014. REGISTRO DE CANDIDATURA. DEPUTADO FEDERAL. RECURSO ORDINÁRIO. TOMADA DE CONTAS ESPECIAL. NÃO PRESTAÇÃO DE CONTAS. TRIBUNAL DE CONTAS DA UNIÃO. PREFEITO. ORDENADOR DE DESPESAS. INQUÉRITO POLICIAL. INELEGIBILIDADE. ALÍNEA g. CARACTERIZAÇÃO. AGRAVO DESPROVIDO.

1. A tomada de contas especial rejeitada de prefeito que age como ordenador de despesas e que se manteve inerte ao ser instado a comprovar a regular aplicação dos recursos federais transferidos mediante convênio incidem em causa de inelegibilidade, nos termos do disposto na alínea g do art. 10, inciso 1, da Lei Complementar n. 64/90.

2. A irregularidade verificada pela Corte de Contas é insanável, porquanto não houve comprovação de que parcela dos recursos recebidos por meio de convênio foi efetivamente aplicada ao fim a que se destinava, afrontando os princípios da Administração e ferindo o interesse público.

3. O arquivamento do inquérito criminal, em razão, dentre outros motivos, da "impossibilidade de constatar o destino de parte dos recursos subjacentes ao convênio 12/91", não afasta a inelegibilidade descrita na alínea $\mathrm{g}$ da Lei Complementar n. 64/90, com as alterações constantes da LC n. 135/2010.

4. Agravo regimental a que se nega provimento. (TSE; Agravo Regimental No Recurso Ordinário n. 561-08. 
2014.6.08.0000 - Classe 37 - (...); Relatora Ministra Maria Thereza Rocha de Assis Moura)

Depreende-se da fundamentação da jurisprudência citada que a Tomada de Contas Especial referiu-se à omissão de prestar dos recursos recebidos por Município em razão de convênio. A inelegibilidade ocorreu pelo fato da omissão combinada com as inúmeras oportunidades, todas infrutíferas, dadas ao ente para esclarecer sobre destinação correta dos repasses. Em face disso, a ministra relatou que,

em decorrência da omissão do agravante, ficou caracterizada a revelia, bem como se demonstrou o evidente descaso do agente público com a obrigatoriedade de prestar contas. É evidente que a omissão causou prejuízos ao Município, pois, nos termos do art. $25, \S 1^{\circ}, \mathrm{IV}$, a, da Lei de Responsabilidade Fiscal, uma das exigências para a transferência voluntária de recursos é a prestação de contas de recursos anteriormente 'recebidos'.

Nessa senda, ante a impossibilidade de se comprovar a correspondência entre o recurso recebido (pela omissão das contas e inexistência de manifestação na oportunidade da Tomada de Contas Especial) e o gasto realizado pela prefeitura, em razão do dolo decorrente da omissão de prestar contas, concluiu a relatora que

Assim, a não apresentação de contas enseja evidente prejuízo ao Município e configura ato de improbidade administrativa, nos termos do art. 11, VI, da Lei n. 8.492/92 e, pôr consequência, atrai a incidência da inelegibilidade prevista no art. 1, I, g, da LC n. 64/90.

Portanto, outro reflexo importante da Tomada de Contas Especial está no fato de ela coibir práticas ímprobas, tendo em vista que, se constatados o dolo e o prejuízo, poderá ser imputado ao gestor a inelegibilidade. Para elucidar a importância do instituto nesse quesito, outro importante julgado do TSE deve ser colacionado, relatando a possibilidade de tornar pessoa inelegível em razão de Tomada de Contas Especial procedente, cumulada com outros requisitos:

ELEIÇÕES 2014. CANDIDATO A DEPUTADO FEDERAL. REGISTRO DE CANDIDATURADEFERIDO. ART. $1^{\circ}$, INCISO I, ALÍNEAS $g$ E $l$, DA LC N. 64/1990. NÃO INCIDÊNCIA NAS INELEGIBILIDADES.

1. A jurisprudência firmada por este Tribunal nas eleições de 2014 é no sentido de que a competência para julgar as contas de gestão de prefeito é do Tribunal de Contas. Ressalva de entendimento pessoal.

2. Irregularidades em procedimentos licitatórios: ausência de pesquisa de mercado e exigência de que o interessado 
declare estar de acordo com todos os termos do edital. Falta de planejamento administrativo, segundo o TCE. Ausência de dano ao erário. Vício formal ou conduta culposa. Inelegibilidade decorrente de rejeição de contas públicas. Não caracterização.

3. Na linha da pacífica jurisprudência do TSE, para a incidência na inelegibilidade prevista na alínea $l$, há que se observar, entre outros requisitos, a condenação cumulativa nos arts. $9^{\circ}$ e 10 da Lei n. 8.429/1992, que impõem sanção quanto ao enriquecimento ilícito e ao dano ao erário.

4. Recurso desprovido.

(...) O SENHOR MINISTRO GILMAR MENDES (relator): Senhor Presidente, inicialmente, anoto que a jurisprudência firmada por este Tribunal nas eleições de 2014 é no sentido de que a competência para julgar as contas de gestão de prefeito é do Tribunal de Contas (RO n. 401-37/CE, rel. Min. Henrique Neves da Silva, julgado em 26.8.2014), ressalvado entendimento pessoal.

Superada essa alegação, passo a analisar se o recorrido incide na causa de inelegibilidade prevista no art. $1^{\circ}$, inciso I, alínea g, da LC n. 64/1990, considerando que a $2^{\circ}$ Câmara do TCM/CE julgou procedente Tomada de Contas Especial da Prefeitura Municipal de lbicuitinga, em razão de ilegalidades nos procedimentos licitatórios Convite n. 1/2000-003 e 1/2000-004, durante o período em que o pretenso candidato era o chefe do Executivo municipal.

Essa causa de inelegibilidade não é imposta pela decisão do Tribunal de Contas, mas pode ser efeito secundário em âmbito administrativo, verificável no momento em que o cidadão requerer o registro de sua candidatura, como fez o recorrido em 2014.

(...) Importante frisar que nem toda desaprovação de contas enseja a causa de inelegibilidade do art. $1^{\circ}$, inciso I, alinea g, da LC n. 64/1990, somente as que preenchem os requisitos cumulativos constantes dessa norma, assim enumerados:

i) decisão do órgão competente;

ii) decisão irrecorrivel no âmbito administrativo;

iii) desaprovação devido a irregularidade insanável;

iv) irregularidade que configure ato doloso de improbidade administrativa;

v) prazo de oito anos contados da decisão não exaurido;

vi) decisão não suspensa ou anulada pelo Poder Judiciário. 
(...) Assim, embora as condutas tenham levado à procedência da Tomada de Contas Especial e, consequentemente, às sanções impostas na decisão do TCM/CE, não verifico elementos mínimos que revelem ato de improbidade administrativa praticado na modalidade dolosa, pois não há na decisão má-fé do gestor público, desvio de recursos públicos em benefício próprio ou de terceiros, dano ao erário, reconhecimento de nota de improbidade, grave violação a princípios, entre outros, entendidos assim como condutas que de fato lesem dolosamente o patrimônio público ou que prejudiquem a gestão municipal." (RECURSO ORDINÁRIO N. 679-38.2014.6.06.0000 - CLASSE 37 FORTALEZA - CEARÁ; Relator Ministro Gilmar Mendes) (grifo nosso).

Do julgado, percebe-se que a simples constatação de ato de improbidade administrativa não bastaria para gerar a inelegibilidade, pois há necessidade de se comprovar conduta dolosa decorrente de má-fé, desvio de recursos públicos etc., sendo imprescindível a comprovação de lesão ao patrimônio público ou ato que prejudique a gestão do ente.

De rigor aceitar que a Tomada de Contas Especial não tornará inelegível, imediatamente, o agente que causou prejuízo ao erário. Contudo, seu julgamento servirá como substrato fático para que Juízes Eleitorais, Tribunais Eleitorais e Tribunal Superior Eleitoral possam impedi-lo de se eleger.

Impende salientar, ademais, que as Cortes de Contas já trabalham em conjunto com a Justiça Eleitoral, na medida em que, por determinação da Lei n. 9.504/97, conhecida como Lei das Eleições, incumbe ao Tribunal enviar relação de gestores públicos que tiveram suas contas rejeitadas em razão de irregularidade insanável e por decisão irrecorrível do órgão competente, in verbis:

Art. 11. Os partidos e coligações solicitarão à Justiça Eleitoral o registro de seus candidatos até as dezenove horas do dia 15 de agosto do ano em que se realizarem as eleições. (Redação dada pela Lei n. 13.165, de 2015).

(...) $\S 5^{\circ}$ Até a data a que se refere este artigo, os Tribunais e Conselhos de Contas deverão tornar disponiveis à Justiça Eleitoral relação dos que tiveram suas contas relativas ao exercício de cargos ou funções públicas rejeitadas por irregularidade insanável e por decisão irrecorrivel do órgão competente, ressalvados os casos em que a questão estiver sendo submetida à apreciação do Poder Judiciário, ou que haja sentença judicial favorável ao interessado.

(...) $\S 10$. As condições de elegibilidade e as causas de inelegibilidade devem ser aferidas no momento da formalização do pedido de registro da candidatura, 
ressalvadas as alterações, fáticas ou jurídicas, supervenientes ao registro que afastem a inelegibilidade. (g. n.).

A relação mutualística é notória entre Justiça Eleitoral e Administrativa, visto que, a inelegibilidade decorrente de irregularidade das contas é consequência do envio dos nomes de gestores que tiveram suas contas julgadas irregulares para formação de cadastro com candidatos elegíveis e inelegíveis. Tal fato reforça a necessidade da regulamentação da Tomada de Contas Especial, mormente do campo contratual, haja vista que a irregularidade insanável desse instrumento não implicaria, em outras análises, a irregularidade da prestação de contas do gestor. Ou seja, a simples irregularidade do contrato não bastaria para incluir o responsável no cadastro a ser enviado à Justiça Eleitoral para possível inelegibilidade, uma vez que, em sua prestação de contas, outros aspectos poderiam convencer o Ministro ou Conselheiro a alocar a irregularidade do processo no campo das recomendações.

\section{É interessante destacar que a Lei n. 9.504/1997 prevê um diálogo institucional} muito importante entre Tribunais de Contas e Justiça Eleitoral, porquanto esta, conforme o art. $11, \S 5^{\circ},{ }^{8}$ da Lei mencionada, recebe daqueles uma lista dos que tiverem suas contas rejeitadas. Para fins ilustrativos, destaque-se que o Tribunal de Contas do Estado de Santa Catarina, em atenção a esse dispositivo, já elabora essa lista de gestores públicos com contas rejeitadas, conforme se depreende do seguinte julgado:

Diante do exposto, proponho ao Egrégio Tribunal Pleno a adoção da seguinte deliberação:

[...]

3.3. Incluir, com respaldo no art. 11, caput e inciso I, da Lei Federal n. 8.429/1992, no art. $1^{\circ}$, inciso I, alínea "g" da Lei Complementar n. 64, de 18 de maio de 1990, com a redação alterada pela Lei Complementar n. 135, de 4 de junho de 2010, no art. 11, $\S 5^{\circ}$, da Lei n. 9.504, de 30 de setembro de 1997, no art. 114 da Lei Complementar Estadual n. 202, de 15 de dezembro de 2000, e no parágrafo único do art. $1^{\circ}$ da Resolução n. 64/2012 desta Corte de Contas, os nomes do Sr. (...) e do Sr. (...) na relação dos responsáveis por irregularidades insanáveis, que configurem ato doloso de improbidade administrativa, a ser encaminhada à Justiça Eleitoral até 5 de julho do próximo ano eleitoral. (REP10/00817110, TCESC, Tribunal Pleno, Rel. Cons. Adircélio de Moraes Ferreira Júnior, j. 3/9/2012).

\footnotetext{
"Até a data a que se refere este artigo, os Tribunais e Conselhos de Contas deverão tornar disponíveis à Justiça Eleitoral relação dos que tiveram suas contas relativas ao exercício de cargos ou funções públicas rejeitadas por irregularidade insanável e por decisão irrecorrível do órgão competente, ressalvados os casos em que a questão estiver sendo submetida à apreciação do Poder Judiciário, ou que haja sentença judicial favorável ao interessado."
} 
Assim sendo, a instauração da TCE em razão de algum prejuízo decorrente de contrato, se julgada procedente, seria suficiente para impedir o gestor de se candidatar a cargo político caso a Justiça Eleitoral entenda pela sua inelegibilidade, motivo que se coaduna com o ideário de moralidade administrativa, colabora com a administração gerencial implantada pela EC n. 19/98 e produz os efeitos práticos do preâmbulo da Lei Complementar n. 135/2010 (Ficha Limpa). E a presente inelegibilidade, evitando que o gestor ímprobo e ineficiente prejudique o erário novamente, pode ser fruto da Tomada de Contas Especial, instrumento essencial para manutenção da probidade e eficiência administrativa, princípios basilares da administração gerencial.

E como a TCE pode ser estendida aos contratos, os dirigentes das grandes empresas estatais, que não raro estão envolvidos em denúncias de superfaturamento de contratos de obras, podem ser responsabilizados, também, no campo da justiça eleitoral.

Tal remissão torna-se de grande importância, haja vista que as referidas empresas prestam contas da mesma forma que a Administração Direta. No entanto, elas se limitam a exercer atividades econômicas, que são atendidas, na maioria dos casos, por meio de contratações de obras e efetivação de aquisições - esses gastos perfazem quase a totalidade de sua movimentação financeira. Ao contrário da Administração Direta, que presta contas nas áreas de educação, saúde, segurança, moradia, cultura etc., no caso das estatais, isso não ocorre. $\mathrm{O}$ que fica reservado à prestação de suas contas anuais, são questões meramente contábeis, que dificilmente enfrentará problemas. Portanto, o gestor de uma grande estatal que participa de fraude em contratos, pode ter suas contas anuais tidas por regulares, e ver, após alguns anos, a decisão de uma irregularidade contratual em processo comum, e que não enseja, neste último caso, inelegibilidade.

7.3. Retorno potencial, transparência, credibilidade administrativa e participação popular

O prejuízo decorrente da conduta ímproba dos gestores de verbas públicas é o principal objetivo a ser perseguido e dirimido pela autotutela administrativa. Os meios de controle funcionam como importante parâmetro para situar a administração (i) quantificando o prejuízo gerado aos cofres públicos; (ii) reconhecendo autoria e materialidade da conduta inadequada; e (iii) possibilitando retorno potencial decorrente do sucesso do procedimento especialíssimo.

O procedimento bem estruturado, apoiado por um aparato administrativo adequado, à luz dos três parâmetros mencionados, redunda em retorno significativo não apenas no que tange ao aspecto financeiro, mas também no que concerne à credibilidade do Estado para com os administrados, visto que, por meio de um banco de dados, o órgão 
da Fiscalização poderá realizar levantamento das principais causas e condutas que deem causa à investigação pormenorizada dos fatos.

A estrutura do controle externo, com base nesses indicadores, poderá ser alterada para combater de modo mais eficaz e eficiente. Haveria, portanto, uma especialização para combate de práticas infracionais. Cada conduta ímproba possui uma especificidade ímpar. Omissão do dever de prestar contas, não comprovação de recursos repassados, desfalque de recursos públicos, prática de ato ilegal, ilegítimo ou antieconômico, perda, extravio ou outra irregularidade de que resulte dano ao erário são práticas que ocorrem em determinada quantidade e de certo modo, razão pela qual o levantamento da frequência em que cada tipo ocorre seria de grande valia para o Tribunal definir como atuará nos casos que tais.

Saliente-se também que a transparência administrativa decorrente do levantamento sugerido não se mostra inviável de se realizar, uma vez que a ControladoriaGeral da União já demonstrou ser possível realização do estudo mencionado. ${ }^{9}$

O primeiro gráfico a ser analisado versa sobre a relação entre quantidade de Tomada de Contas Especial efetuadas pela CGU, quantas foram encaminhadas para o TCU e o retorno potencial que as TCE's podem trazer aos cofres públicos: ${ }^{10}$

\begin{tabular}{|c|r|r|r|r|}
\hline Exercícios & $\begin{array}{c}\text { Análises } \\
\text { de TCE's } \\
\text { Efetuadas }\end{array}$ & $\begin{array}{c}\text { Diligenciadas ao } \\
\text { Órgão de Origem }\end{array}$ & $\begin{array}{c}\text { Certificadas ao } \\
\text { TCU }\end{array}$ & $\begin{array}{c}\text { Retorno Potencial } \\
\text { (R\$) }\end{array}$ \\
\hline $\mathbf{2 0 0 2} \mathbf{- 2 0 0 9}$ & 13.409 & 2.922 & 10.487 & $4.249 .716 .084,03$ \\
\hline $\mathbf{2 0 1 0}$ & 1.481 & 375 & 1.106 & $1.685 .274 .158,37$ \\
\hline $\mathbf{2 0 1 1}$ & 1.149 & 405 & 744 & $1.783 .369 .651,31$ \\
\hline $\mathbf{2 0 1 2}$ & 1.688 & 414 & 1.274 & $1.453 .300 .009,34$ \\
\hline $\mathbf{2 0 1 3}$ & 2.127 & 204 & 1.923 & $2.520 .489 .158,45$ \\
\hline $\mathbf{2 0 1 4}$ & 2.500 & 178 & 2.322 & $1.381 .037 .790,38$ \\
\hline $\mathbf{2 0 1 5}$ & 2.633 & 196 & 2.437 & $2.795 .723 .054,33$ \\
\hline TOTAL & $\mathbf{2 4 . 9 8 7}$ & $\mathbf{4 . 6 9 4}$ & $\mathbf{2 0 . 2 9 3}$ & $\mathbf{1 5 . 8 6 8 . 9 0 9 . 9 0 6 , 2 1}$ \\
\hline
\end{tabular}

A presente tabela, fruto do trabalho feito pela CGU, é um documento público e de livre acesso a qualquer cidadão brasileiro. A publicação dos referidos valores

9 BRASIL. Ministério da Transparência, Fiscalização e Controladoria-Geral da União. Realizações na auditoria de tomada de contas especial. Disponível em: <http://www.cgu.gov.br/assuntos/auditoria-efiscalizacao/avaliacao-da-gestao-dos-administradores/tomadas-de-contas-especiais/realizacoes $>$. Acesso em: 5 abr. 2016.

10 BRASIL. Ministério da Transparência, Fiscalização e Controladoria-Geral da União. Tomada de contas especial. Disponível em: <http://www.cgu.gov.br/assuntos/auditoria-e-fiscalizacao/avaliacao-da-gestaodos-administradores/tomadas-de-contas-especiais>. Acesso em: 5 abr. 2016. 
serve de estímulo para que a sociedade participe da administração exercendo o controle social desses gastos e a cobrança dos gestores que deram causa ao prejuízo. Funciona como um incentivo para que o cidadão fiscalize seus gestores, o que se mostra razoável levando-se em consideração que o gestor destinou incorretamente dinheiro público que deveria ser destinado a alguma função de interesse público da administração, ou seja, de interesse da sociedade.

Ao mesmo tempo, a reprovação social da conduta ímproba serve como desestímulo para que essas práticas se perpetuem como praxe na administração pública. O controle social em questão, portanto, colabora com a probidade administrativa e com a administração gerencial.

Como exemplo da intervenção e consequente auxílio do controle social temse o fato de que a instauração da Tomada de Contas Especial pode decorrer da conversão de denúncias ou representações ${ }^{11}$ oferecidas por qualquer cidadão. Nesse sentido, o particular que vislumbrar alguma atitude indevida de gestor que possa ocasionar dano à administração poderá denunciar o fato para que a autoridade competente analise e, se for o caso, converta o processo em TCE, cabendo, inclusive, ao Tribunal de Contas “determinar a conversão em TCE de processo de fiscalização ou denúncia” (LIMA, 2011, p. 283) por conta própria.

Julgados do TCU demonstram a possibilidade da instauração de TCE decorrente de conversão de denúncia ou representação:

TOMADA DE CONTAS ESPECIAL DECORRENTE
DE DENÚNCIA ACERCA DE SUPOSTA
IRREGULARIDADE VERIFICADA NO CONSELHO
FEDERAL DE ENGENHARIA, ARQUITETURA E
AGRONOMIA-CONFEA RELATIVAAO PAGAMENTO
DE INDENIZAÇÕES POR DANOS MORAIS
DECORRENTES DE CONDENAÇÃO EM AÇÕES
TRABALHISTAS. RESPONSABILIDADE OBJETIVA
DO CONFEA. NECESSIDADE DE INTERPOSIÇÃO
DE AÇÃO DE REGRESSO, NA VIA JUDICIAL,
PARA RESTITUIÇÃO DO DANO AOS COFRES DA
ENTIDADE, CONSOANTE O DISPOSTO NOART. $37, \S$
$6^{\circ}$, DA CONSTITUIÇÃO FEDERAL. ARQUIVAMENTO
DOS AUTOS.

Trata-se da Tomada de Contas Especial originária de processo de Denúncia sobre irregularidades verificadas no âmbito do Conselho Federal de Engenharia, Arquitetura e

\footnotetext{
11 BRASIL. Tribunal de Contas da União. Tomadas de conta especial (TCE). Disponível em: <http://portal. tcu.gov.br/contas/tomada-de-contas-especial/conheca-a-tomada-de-contas-especial.htm>. Acesso em: 5 abr. 2016.
} 
Agronomia - Confea, acerca do pagamento, com recursos do Conselho, de indenizações por danos morais causados a terceiros decorrentes de condenação definitiva em ações trabalhistas movidas por ex-empregadas contra a entidade, nas quais se alegava assédio moral por parte da Sra. Carmem Eleonôra Cavalcanti Amorim Soares, exAssessora para Assuntos Internacionais do Conselho. Mediante o Acórdão n. 538/2012 - Plenário (Peça n. 27, p. 1/2), o TCU converteu a Denúncia em Tomada de Contas Especial, com vistas a promover a citação da exAssessora para Assuntos Internacionais da entidade para que oferecesse alegações de defesa ou recolhesse o débito quantificado nos autos. (Acórdão n. 7796/2014 - TC006.978/2012-6 [Apenso: TC-030.461/2011-1]; Natureza: Tomada de Contas Especial; Entidade: Conselho Federal de Engenharia, Arquitetura e Agronomia - Confea; 2/12/2014). (grifo nosso)

TOMADA DE CONTAS ESPECIAL. CONVERSÃO DE REPRESENTAÇÃO. CITAÇÃO. REVELIA. DESVIO DE RECURSOS. RESPONSABILIZAÇÃO SOLIDÁRIA. DÉBITO. MULTA. ACÓRDÃO 8.046/2010-TCU-1 ${ }^{\mathrm{a}}$ CÂMARA. RECURSO DE RECONSIDERAÇÃO. ELEMENTOS COMPLEMENTARES. CONHECIMENTO. NEGATIVA DE PROVIMENTO. ACÓRDÃO 5.487/2013-TCU-1 ${ }^{\text {a }}$ CÂMARA. EMBARGOS DE DECLARAÇÃO. CONHECIMENTO. REJEIÇÃO.

(...) Originalmente, os autos cuidaram de representação, convertida em tomada de contas especial (TCE) por determinação do Acórdão 1.650/2009-TCU-1 ${ }^{a}$ Câmara. As irregularidades que ensejaram a responsabilização do recorrente dizem respeito a desvio de recursos do convênio supracitado, sacados da conta específica do ajuste e depositados em contas correntes de pessoas físicas, sem comprovação de ligação com o objeto do convênio. (Acórdão n. 6733/2014 - TC 009.228/2009-7; Natureza: Embargos de Declaração - Recurso de Reconsideração/ Tomada de Contas Especial; Entidade: Município de Apiacás/MT; 28/10/2014). (grifo nosso).

Como exemplo de estímulo ao controle social, tem-se a ControladoriaGeral do Estado de Minas Gerais, incentivando que denúncias online sejam feitas por particulares em seu endereço eletrônico, ${ }^{12}$ dispondo que "Este Canal de Denúncias destina-se exclusivamente ao recebimento de manifestações que têm por objeto a alegação

12 MINAS GERAIS. Controladoria-Geral do Estado de Minas Gerais - CGE. Canal de denúncias. Disponível em: <http://controladoriageral.mg.gov.br/cidadao/denuncias>. Acesso em: 5 abr. 2016. 
de corrupção (obtenção de vantagem indevida ou cobrança de propinas), irregularidade ou ilegalidade no serviço público ou fora dele que possa ou tenha causado prejuízo de qualquer espécie à Administração Pública Estadual (Resolução CGE n. 12/2015)”.

Outrossim, o Tribunal de Contas, observando os números levantados pela Controladoria, poderá traçar metas e objetivos para restituir ao erário o máximo possível do retorno potencial. Determinações estratégicas, pautando-se na logística adequada e condizente com a conjuntura atual do tipo de prejuízo configurado, poderão ser decididas pelos Tribunais com intuito de ressarcir o erário e, além disso, diminuir a incidência desses ilícitos e atos de improbidade. Para tanto, a administração gerencial necessita de aparato técnico capaz de quantificar tais prejuízos enquadrando-os em tipos mais frequentes, à medida que organização para combate ao prejuízo ao erário decorrente de atitude ímproba se mostra essencial. Nessa toada, a CGU também elaborou estudos complementares (link já mencionado da GCU) referentes a "Fatos motivadores da instauração de processos de Tomada de Contas Especial":

\begin{tabular}{|c|r|r|r|r|r|r|r|r|}
\hline Motivo & $\mathbf{2 0 0 2 - 2 0 0 9}$ & $\mathbf{2 0 1 0}$ & $\mathbf{2 0 1 1}$ & $\mathbf{2 0 1 2}$ & $\mathbf{2 0 1 3}$ & $\mathbf{2 0 1 4}$ & $\mathbf{2 0 1 5}$ & TOTAL \\
\hline $\begin{array}{c}\text { Omissão no dever de } \\
\text { prestar contas }\end{array}$ & 4.054 & 245 & 102 & 131 & 422 & 355 & 349 & 5.658 \\
\hline $\begin{array}{c}\text { Irregularidades na } \\
\text { aplicação dos recursos }\end{array}$ & 2.288 & 243 & 204 & 429 & 660 & 963 & 1336 & 6.123 \\
\hline $\begin{array}{c}\text { Não cumprimento do } \\
\text { objeto conveniado }\end{array}$ & 1.485 & 235 & 211 & 326 & 377 & 361 & 379 & 3.374 \\
\hline $\begin{array}{c}\text { Prejuízos causados por } \\
\text { servidor ou empregado } \\
\text { público }\end{array}$ & 827 & 109 & 45 & 104 & 59 & 98 & 87 & 1.348 \\
\hline $\begin{array}{c}\text { Não aprovação da } \\
\text { prestação de contas }\end{array}$ & 1.161 & 54 & 54 & 103 & 145 & 335 & 192 & 2.046 \\
\hline $\begin{array}{c}\text { Irregularidade } \\
\text { praticada por bolsista } \\
\text { ou pesquisador }\end{array}$ & 380 & 111 & 4 & 6 & 19 & 74 & 25 & 619 \\
\hline $\begin{array}{c}\text { Irregularidade } \\
\text { na cobrança de } \\
\text { procedimentos do SUS }\end{array}$ & 266 & 72 & 106 & 77 & 117 & 72 & 34 & 744 \\
\hline $\begin{array}{c}\text { Outros } \\
\text { TOTAL }\end{array}$ & $\mathbf{1 0 . 4 8 7}$ & $\mathbf{1 . 1 0 6}$ & $\mathbf{7 4 4}$ & $\mathbf{1 . 2 7 4}$ & $\mathbf{1 . 9 2 3}$ & $\mathbf{2 . 3 2 2}$ & $\mathbf{2 . 4 3 7}$ & $\mathbf{2 0 . 2 9 3}$ \\
\hline
\end{tabular}

Conclui-se dos dados levantados os tipos de condutas inadequadas que comumente redundam na instauração da Tomada de Contas Especial. A administração, a partir deles, pode alocar esforços para combater de forma mais incisiva um tipo mais 
frequente, sendo possível, outrossim, o aperfeiçoamento da técnica fiscalizatória com base no desempenho obtido das TCEs oriundas de determinada prática ilegal.

O instituto da TCE servirá como indicador útil e desejável para planejamento e organização do modus operandi da Fiscalização em seu sentido mais amplo, sendo um instrumento de grande valia para eficiência e probidade administrava, haja vista o retorno potencial aliado à coibição da conduta ímproba, além de facilitar a organização gerencial da administração pública.

A prática mencionada já é realidade, por exemplo, da organização Fiscalizatória do Estado de Minas Gerais, uma vez que sua Controladoria-Geral elabora diagnóstico das Tomadas de Contas Especial, ${ }^{13}$ no âmbito Estadual, produzindo relatórios que servirão como balizas, metas e objetivos a serem perseguidos para os anos subsequentes.

\section{Conclusão}

Terminada a exposição precedente, pensamos estar demonstrada a tese inicial.

Após fornecer um breve panorama sobre o dever de prestar contas, tentou-se desenvolver uma exposição concisa, porém abrangente, do conceito da Tomada de Contas Especial. À luz do quanto exposto, restou demonstrado que, na experiência nacional, alguns estados brasileiros, embora possuam meios próprios de controle, não apresentam a regulamentação pormenorizada desse instrumento em meios infraconstitucionais - Leis Orgânicas e Regimentos Internos dos Tribunais de Contas dos Estados.

Buscou-se mostrar, ainda que a título exemplificativo, algumas benesses decorrentes da utilização da TCE, bem como sua conformidade com os ideais de administração gerencial e economicidade da Administração Pública. Isto é, demonstrar, se não a necessidade, a vantagem de regulamentar e fazer valer essa importante ferramenta do controle externo.

E por fim, tem-se o grande diferencial em relação aos dirigentes das estatais, porquanto, ao contrário do que sói acontecer em suas prestações de contas ordinárias, na Tomada de Contas Especial eles podem sofrer as mesmas punições que os demais agentes políticos, como por exemplo, prefeitos, vereadores, dentre outros.

São Paulo, 28 de abril de 2016.

13 MINAS GERAIS. Controladoria-Geral do Estado de Minas Gerais - CGE. Tomada de contas especial. Disponível em: <http://www.controladoriageral.mg.gov.br/auditoria/tomada-de-contas-especial>. Acesso em: 5 abr. 2016. 


\section{Referências}

ÁVILA, Humberto. Teoria da segurança jurídica. 3. ed. São Paulo: Malheiros, 2014.

BEDAQUE, José Roberto dos Santos. Direito e processo: influência do direito material sobre o processo. 6. ed. São Paulo: Malheiros, 2011.

BRASIL. Ministério da Transparência, Fiscalização e Controladoria-Geral da União. Realizações na auditoria de tomada de contas especial. Disponível em: <http://www.cgu.gov.br/assuntos/ auditoria-e-fiscalizacao/avaliacao-da-gestao-dos-administradores/tomadas-de-contas-especiais/ realizacoes>. Acesso em: 5 abr. 2016.

BRASIL. Ministério da Transparência, Fiscalização e Controladoria-Geral da União. Tomada de contas especial. Disponível em: <http:/www.cgu.gov.br/assuntos/auditoria-e-fiscalizacao/ avaliacao-da-gestao-dos-administradores/tomadas-de-contas-especiais>. Acesso em: 5 abr. 2016.

BRASIL. Tribunal de Contas da União. Tomadas de conta especial (TCE). Disponível em: $<\mathrm{http}: / /$ portal.tcu.gov.br/contas/tomada-de-contas-especial/conheca-a-tomada-de-contas-especial.htm>. Acesso em: 5 abr. 2016.

BRESSER-PEREIRA, Luiz Carlos. Da administração pública burocrática à gerencial. Revista do Serviço Público, Brasília: v. 47, n. 1, p. 7-40, jan./abr., 1996.

CARVALHO FILHO, José dos Santos. Manual de direito administrativo. 26. ed. São Paulo: Atlas, 2013.

FERREIRA FILHO, Manoel Gonçalves. Curso de direito constitucional. 24. ed. São Paulo: Saraiva, 1997.

JACOBY FERNANDES, Jorge Ulisses. Tomada de contas especial: processo e procedimento na Administração Pública e nos Tribunais de Contas. 6. ed. rev., atual. e ampl. Belo Horizonte: Fórum, 2014.

JUSTEN FILHO, Marçal. Comentários à lei de licitações e contratos administrativos. 15. ed. São Paulo: Dialética, 2012.

LEITE, Harrison. Manual de direito financeiro. 5. ed. Salvador: JusPodivm, 2016.

LENZA, Pedro. Direito constitucional esquematizado. 17. ed. São Paulo: Saraiva, 2013.

LIMA, Luiz Henrique. Controle externo: teoria, jurisprudência e mais de 500 questões. 4. ed. Rio de Janeiro: Elsevier, 2011. (Série Provas \& Concursos).

MINAS GERAIS. Controladoria-Geral do Estado de Minas Gerais - CGE. Canal de denúncias. Disponível em: <http://controladoriageral.mg.gov.br/cidadao/denuncias $>$. Acesso em: 5 abr. 2016. 
MINAS GERAIS. Controladoria-Geral do Estado de Minas Gerais - CGE. Tomada de contas especial. Disponível em: <http://www.controladoriageral.mg.gov.br/auditoria/tomada-de-contasespecial>. Acesso em: 5 abr. 2016.

OLIVEIRA, Regis Fernandes de. Curso de direito financeiro. 5. ed. São Paulo: Revista dos Tribunais, 2013.

REIS, Sérgio Oliva. Do conceito de dano ao erário para prestação de contas. Revista Controle Doutrina e Artigos, Fortaleza, v. 7, p. 115-124, abr. 2009.

SILVA, Antonio Paulo da. Tomada de contas especial: uma medida de exceção no controle administrativo. Revista Controle - Doutrina e Artigos, Fortaleza: v. 8, p. 153-170, set. 2010.

SIMÃO, Calil. Lei de improbidade administrativa. Comentada. Estudo em comemoração aos 20 anos da lei de improbidade administrativa. Leme: J. H. Mizuno, 2011. 
